\title{
SOUTH AMERICAN RECOVERIES \\ OF FRANKLIN'S GULLS AND SWAINSON'S HAWKS BANDED IN SASKATCHEWAN
}

\author{
by C. STUART HOUSTON*
}

While the gardener studies his spring catalogues and the golfer receives vicarious satisfaction watching television matches in sunnier climes, the bird bander's winter is brightened up by monthly batches of recoveries from the banding office. The greatest thrill of all is a recovery from another continent.

After my first 27 years of banding, my most distant recoveries were of a Pectoral Sandpiper far inside Siberia and a Common Tern from the Cook Islands. ${ }^{4}:$ Interesting waterfowl recoveries included a Pintail shot near Anadyr'. Chukotka, U.S.S.R., and six Blue-winged Teal shot in South America, two in Venezuela and four in Colombia.

Well aware of Fred Bard's banded Franklin's Gull recovered in Peru and of Hartley Fredeen's Swainson's Hawk recovered in northern Argentina, I patiently but confidently waited many years for my first South American recoveries of these two species. " The past two winters have finally produced the following reports, including one from Central America.

Franklin's Gull (banded as flightless young) 564-38468, Banded July 6, 1972, at Rice Lake,

*863 University Drive, Saskatoon, Saskatchewan. S7N 0J8.
19 miles west of Saskatoon $(520-1070)^{* *}$

The banding crew that day included Stuart, Mary and David Houston, Arnold Nijssen, Waync Renaud, Alan Smith, Allan Moulin and Murray Akre. The gull was found dead February 3, 1973 by Rigoberto Guerra-V. at Puerto Caldera, Chile (270 South - 0705).

Swainson's Hawk (all banded as nestlings).

787-85464. Banded July 19, 1970, in nest found by Nancy Robinson on Bob Robinson's farm west of Simpson (513-1054). Shot May 5, 1971, by Eligio Walter on his ranch 9 kilometers southwest of Susana, which in turn is $10 \mathrm{~km}$. south of Rafaela, in the province of Santa Fe, Argentina (312 South - 0614).

787-85406. Banded July 19, 1969, thanks to Gary Anweiler, at the north end of Last Mountain Lake (512-1051). Shot February 29, 1972, by Atilio Casce at Marcos Juarcz, Argentina (324 South - 0620).

847-90101. Banded July 14, 1968, in a nest reported to me by Dr. Jack Millar, one milc south of Floral (520-1062). Found dead November 30, 1972, by Ricardo Miguel Lawlor near Young, Uruguay (324 South - 0573).

617-21641. Banded August 1, 1971, by subpermittee Wayne C. Harris on Leland Grcenfield's farm west of Govan (512-1050). Shot November 14, 1971, by A. Bernardo Lopez - D., at El Jicaral, El Salvador (140-0894).

617-22125. Banded July 21, 1973, at Smiley (513-1092). Shot November 23, 1973, by Omar Fernandez at Firmat, Sante Fe, Argentina (332 South -0612 ).

\section{Discussion:}

The Chile recovery of the Franklin's Gull was from the Pacific coast, about

\footnotetext{
**520-1070 is the computer coordinate of the ban. ding location. It signifies the 10-degree block bet ween $52^{\circ} 00^{\prime}$ and $52^{\circ} 10^{\circ}$ North and between $107^{\circ}$ $00^{\prime}$ and $107^{\circ} 10^{\prime}$.West. Latitudes are North cxcept when South is specificd.
} 


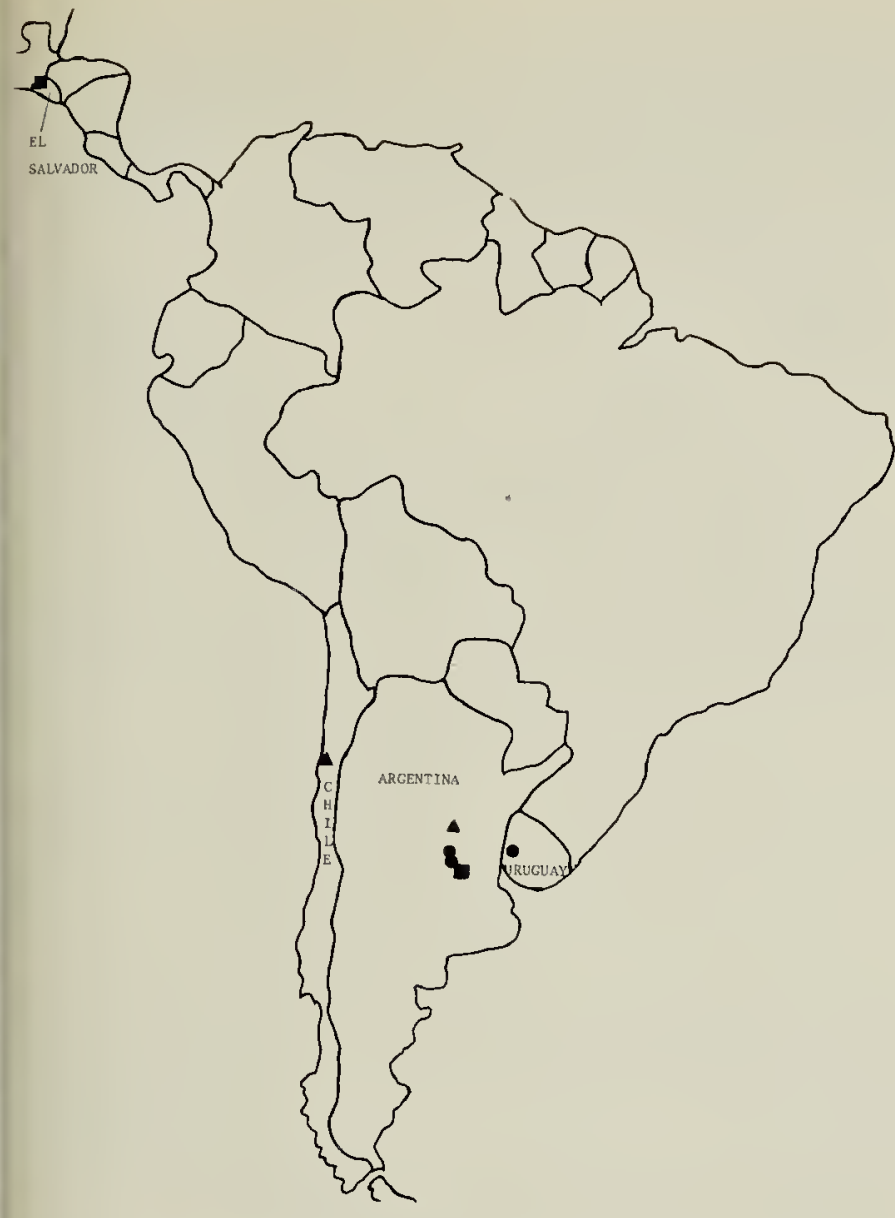

Fig. 1. CHILE: Franklin's Gull. ALL OTHERS: Swainson's Hawks. Squares represent direct recoveries (same year); triangles, January 1 to June 30 of the following year; circles, more than one year old. Southernmost circle was a hawk banded by Hartley Fredeen.

400 miles north of Valparaiso, whereas the winter range of the species extends about 400 miles south of Valparaiso to Mocha Island.'

Louis M. Moos, from 12,535 Franklin's Gulls banded at Freezeout Lake, Montana, has had 21 recoveries, including one from Honduras, four from Peru and two from Chile. ${ }^{7}$

In a similar proportion, I have had only two other recoveries from the 1,177 Franklin's Gulls banded through 1972: one found with a broken wing east of Stalwart, Saskatchewan, August 17 of the year it was banded (1966), and one shot at Lake Texoma, Oklahoma on November 5 of the year it was banded (1970).

The Argentina recoveries of Saskatchewan-banded Swainson's Hawks (including Fredeen's) are all on the west side of and within 80 miles of the
Parana River, from Rosario to a point 100 miles upstream. The Uruguay recovery is within 40 miles east of the Uruguay River, which forms the Argentina-Uruguay boundary. These five recoveries fit within a 250-mile diameter circle, suggesting this is a commonly used portion of the "pampas of Argentina" mentioned as the normal winter range of this hawk. ${ }^{2}$

My Swainson's Hawk recoveries listed above represent one from each of the 5 years, 1968 through 1971, when 22, 64, 40 and 38, respectively, were banded and 1973, when 52 were banded. No extra-continental recoveries were received from the 69 banded prior to and including 1967 , but additional distant recoveries might almost be expected from the 146 banded in the peak year of 1972 and the 83 banded in 1974. I have also had 10 Swainson's recoveries from this continent, six of which have been published previously, including the first state record of this species for Alabama."

The distances involved are impressive - a direct-line distance of 5,700 miles for the Franklin's Gull and about 6,500 miles for the Swainson's Hawks, although the most probable route through Central America would add 700 miles to the latter figure.

'AMERICAN ORNITHOLOG ISTS' UNION, 1957. Check-List of North American hirds. Fifth edition, Baltimore, $691 \mathrm{pp}$.

${ }^{2}$ BROWN, L., and D. AMADON, 1968. Eagles, hawks and falcons of the world. McGraw Hill, New York, 2 vols., 945 pp.

${ }^{3}$ HOUSTON, C. S. 1962. Cornmon Tern recovery from the Cook Istands. Blue Jay 20: 58-59.

'HOUSTON, C. S. 1965. Siberian recovery of Pectoral Sandpiper. Bird Banding 36:112-113.

"HOUSTON, C. S. 1968. Recoveries of Swainson's Hawks handed in Saskatchewan. Blue Jay 26: 8687.

"HOUSTON, C. S. 1970. Saskatchewan hird handers - Fred G. Bard. Blue Jay 28: 150-156.

'MOOS, L. M. 1973. Gull handing in Montana. Proc. Mont. Acad. Sci. 32: 20-23. 